\title{
Assessment of heavy metal exposure around auto body refinishing shops
}

\author{
Hajira Tahir*, Qazi JahanZeb and Muhammad Sultan \\ Department of Chemistry, University of Karachi, Karachi, Pakistan.
}

\begin{abstract}
Accepted 8 October, 2010
Significant number of occupations are present in our society which involves metal pollution. These small operational occupations which are always neglected by governments and other occupational health services are another major factor of metal flow in urban soil. The local auto body refinishing shops are one of these occupations. Workers, soil, plants, air and all environments around these shops are continually exposed by their organic solvents, dust, noise and metal pigments. In the present study, 36 top soil samples including controls were collected from 26 different auto body refinishing shops of the metropolitan city, Karachi. The soil samples were digested by EPA method 3050. The metal contents $\mathrm{Cd}, \mathrm{Co}, \mathrm{Cr}, \mathrm{Cu}, \mathrm{Fe}, \mathrm{Mn}, \mathrm{Mo}, \mathrm{Ni}, \mathrm{Pb}$ and $\mathrm{Zn}$ were analyzed by Atomic Absorption Spectrometery (AAS). The results showed that metal contents in soil samples around auto body shops were mainly contaminated due to the exposure of metal pigments. The silent increase in metal concentration in soil samples may contribute to the accumulation of heavy metals in humans and livestocks through soils and plants which will grow in these areas. The statistical methods of analysis were also applied to find out the t-values, p-values and correlation parameters. The Principal Component Analysis (PCA) was also applied to increase the significance of results.
\end{abstract}

Key words: Metal pollution, occupational health services, heavy metals, livestock.

\section{INTRODUCTION}

Heavy metals are toxic to all living organisms, if they exceed public health limits. They showed negative effects on microbial activities in soil and increases pollution (Duxbury, 1985; Baath, 1989). Many studies showed that dust and sediments are main transporters of heavy metals in the urban environment (Charlesworth and Lees, 1989; Zhou et al., 2007). Contaminated soil is a great threat for hyper accumulated plants, which can affect human health (Baker and Brooks, 1989; Knight et al., 1997). The soil of urban areas were mainly contaminated by the deposition of heavy metals which are emitted from industries, vehicles and burning of wastes. The natural variability in soil composition is very well indicated by the presence of trace elements (Jeffrey and Hudson, 2001;

\footnotetext{
${ }^{*}$ Corresponding author. E-mail: hajirat@uok.edu.pk.
}

Abbreviations: AAS, Atomic Absorption Spectrometery; PCA, principal component analysis; VOC, volatile organic compounds; HAP, hazardous air pollutants; GPS, global positioning system; CNG, compressed natural gas.
Ozan, 2008). Soil contamination is also a well reported health risk issue (Farrell, 2002). Atomic Absorption Spectrometery (AAS) is the most valuable technique for the metal estimation in aqueous samples. Mineral constituents, organic matters, living organisms, air and water are the main composite parts of soil (ISO 11466k, 1995). Human activities like vehicular exhaust, lubricating oil residues, tyre wear particles, weathered street surface and paint components contaminate the soil (Rogge et al., 1993; Cocker et al., 2004). Urbanization and accelerated industrialization are the major factors which are disturbing the urban soil (Omar et al., 2007). Concentration of metals in soil is an indicator of environmental pollution (Manta et al., 2002). For example, traffic pollution can be estimated by measuring the levels of $\mathrm{Pb}, \mathrm{Cu}$ and $\mathrm{Zn}$ in soil (Fergusson and Ryan, 1984). Soil pollution has been of great concern to scientists for many years (Guitao et al., 2008).

Along with other unnoticed occupations, the auto body refinishing is also a big contributor of heavy metals in whole environment and producing occupational hazards, especially in soil. The exposure of paints' affects human 
health causing problems like asthma (Nielsen et al., 1985; Selden et al., 1989). About 5 to $20 \%$ exposed workers are facing asthma (Tornling et al., 1990). Auto body refinishing processes are under great pressure, in order to maintain the environmental regulations (Richards and Pearson, 1998). The auto body painting is the main process of auto body refinishing of shops and it directly affects the atmosphere (AAMA, 1997). In these shops over $80 \%$ of environmental pollution is due to paints (Lowell et al., 1993). It protects from corrosion, improve durability and color. These paints mainly consist of volatile organic compounds (VOC's) which are hazardous air pollutants (HAP's) (U.S. EPA, 1996). Auto body painting is the most costly process in the refinishing shops. Half of the cost of painting vehicles are expended for coating materials, especially paints (Nallicheri, 1993). According to EPA's Toxic Release Inventory, auto body sector has great concern with the reduction of pollutants in the environ-ment (Praschan, 1994). These refinishing shops have serious concern relating to health issues such as cancer, asthma, kidney diseases and disordered central nervous system (Federal Register 61, 1996). VOC's from the exhausts of these locations reacts with atmospheric NO in the presence of sunlight and form ground level ozone layer, which is also a big threat to our environment (Richard et al., 1998).

A number of studies have been done on industrial waste, sediments and water (disaster of Tasman Sprit) (Tahir et al., 2000, 2004, Tahir, 2005; Tahir and Mushtaque, 2005). In this study, our objective is to calculate the concentration of selected metals that is, $\mathrm{Cd}$, $\mathrm{Co}, \mathrm{Cr}, \mathrm{Cu}, \mathrm{Fe}, \mathrm{Mn}, \mathrm{Mo}, \mathrm{Ni}, \mathrm{Pb}$ and $\mathrm{Zn}$ in soil around the auto body refinishing shops. According to our hypothesis, these soil samples are contaminated as compared to control soil samples.

Principal Component Analysis (PCA) is one form of multivariate data evaluation. It is a way of identifying pattern in data and expressing the data in such a way as to highlight their similarities and differences. Where the luxury of graphical representation is not available, PCA is a powerful tool for analyzing data. The other main advantage of PCA is that once we have found these patterns in the data and can compress the data, there could be the reduction of the number of dimensions, without much loss of information (Jolliffe, 2002).

\section{MATERIALS AND METHODS}

\section{Sample collection}

Generally in Pakistan, repairing cars are painted under the sheds of trees, on the soil and in open areas. 26 samples along with 10 controls were collected from Karachi city. The number of samples and controls are different in each town. They are based on the number of autobody refinishing shops in the towns. Soil samples were taken within the radius of $5 \mathrm{~m}$ from the car painting process. Three replicates were taken from each site, then the latter was mixed to get the composite sample. Each sample was taken to represent the area of autobody refinishing shops. The locations were selected to present different areas of autobody refinishing shops in Karachi, Pakistan. Control soil samples were taken from these areas, which do not have autobody refinishing shops within the radius of $3 \mathrm{~km}$. Similarly, three replicates of soil samples were taken from each site. Then, the latter was mixed to get the composite samples. The control locations were selected to present areas, without autobody refinishing shops but other conditions were almost the same. GPS locations and ambient temperature of sampling and control sites are given in Tables 1 and 2 .

\section{Method}

The surface soil (about $0-3 \mathrm{~cm}$ in depth) samples from each site and control locations were collected by Teflon shallow scoop. The samples were stored in brown polyethylene bags, to avoid interaction of u.v radiations.

\section{Sample preparation and analysis}

Samples were oven dried at $60 \pm 2^{\circ} \mathrm{C}$ until moisture contents were removed. $5.0 \mathrm{gm}$ of soil samples (2 $\mathrm{mm}$ sieved) were weighted and digested by wet oxidation method, using $\mathrm{HNO}_{3}(65 \%)$ at $60 \pm 2^{\circ} \mathrm{C}$. After keeping at room temperature, the extract was filtered and the filtrate was collected in a volumetric flask and brought to volume by deionized distilled water. The concentrations of trace metals were estimated by Flame Atomic Absorption Spectrophotometer (A Analyst- 700, Perkin Elmer). Analytical grade reagents and standards were used for the analysis. Statistical analysis of data was also carried out by using Minitab soft ware.

\section{RESULTS AND DISCUSSION}

Tables 1 and 2 show the GPS locations and ambient temperature of sampling and control sites in Karachi city, respectively. Table 3 shows the evaluation of the statistical parameters like range, mean and standard deviation values of group data for the estimated metals of effected and controls samples.

Fe showed the maximum mean concentration value in all samples, among the other analyzed metals obtained during the scraping process of auto body's surfaces. In the scraping process, car's surface (mainly made up of $\mathrm{Fe}$ ) was scrapped with the help of metal tools and this frictionating process allows Fe to drizzle directly on soil surface and later it mix in the soil. Prolong exposure of atomic $\mathrm{Fe}$ or $\mathrm{Fe}_{2} \mathrm{O}_{3}$ causes "siderosis" (Chronic inflammation of the lungs caused by excessive inhalation of dust containing iron salts or particles) (Toda et al., 2005).

$\mathrm{Pb}$ showed the higher mean concentration in the affected and control samples, among all analyzed metals. Karachi is the biggest metropolitan and industrial city of Pakistan, having four major industrial areas (SITE, KITE, HITE and Bin Qasim) and the largest number of petrol, diesel and compressed natural gas (CNG) vehicles are running. Due to vehicular and industrial emissions, the $\mathrm{Pb}$ content showed higher concentration in control samples as compared to other metals. The $\mathrm{Pb}$ exposure affects the membrane permeability of liver, kidney and brain cells 
Table 1. GPS locations and ambient temperatures of sampling sites (Karachi).

\begin{tabular}{|c|c|c|c|c|c|}
\hline $\mathbf{S} / \mathbf{N}$ & Sample & Location & GPS Io & ation & Temperature \\
\hline 1 & KS-1 & Marton quarters (Jahangir Road) & $24^{\circ} 53^{\prime} 16.84^{\prime \prime} \mathrm{N}$ & $67^{\circ} 2^{\prime} 37.19^{\prime \prime} \mathrm{E}$ & $40-45^{\circ} \mathrm{C}$ \\
\hline 2 & KS-2 & Kashmir Road & $24^{\circ} 52^{\prime} 19.92^{\prime \prime} \mathrm{N}$ & $67^{\circ} 2^{\prime} 52.46 " \mathrm{E}$ & $40-45^{\circ} \mathrm{C}$ \\
\hline 3 & KS-3 & PECHS community hall (Shahra e Quaideen) & $24^{\circ} 52^{\prime} 6.28^{\prime \prime} \mathrm{N}$ & $67^{\circ} 3^{\prime} 6.32^{\prime \prime} \mathrm{E}$ & $40-45^{\circ} \mathrm{C}$ \\
\hline 4 & KS-4 & PECHS (Block \# 6) & $24^{\circ} 51^{\prime} 15.31^{\prime \prime} \mathrm{N}$ & $67^{\circ} 3^{\prime} 51.69^{\prime \prime} \mathrm{E}$ & $40-45^{\circ} \mathrm{C}$ \\
\hline 5 & KS-5 & Ghosia Colony (Jamsheed Road) & $24^{\circ} 53^{\prime} 19.37^{\prime \prime} \mathrm{N}$ & $67^{\circ} 3^{\prime} 2.49^{\prime \prime} \mathrm{E}$ & $40-45^{\circ} \mathrm{C}$ \\
\hline 6 & KS-6 & Teen Hatti (Nishter Road) & $24^{\circ} 53^{\prime} 29.31^{\prime \prime} \mathrm{N}$ & $67^{\circ} 2^{\prime} 42.20^{\prime \prime} \mathrm{E}$ & $40-45^{\circ} \mathrm{C}$ \\
\hline 7 & KS-7 & Pehalwan Goth (Gulistan e Juhar) & $24^{\circ} 54^{\prime} 52.57^{\prime \prime} \mathrm{N}$ & $67^{\circ} 8^{\prime} 31.33^{\prime \prime} \mathrm{E}$ & $35-40^{\circ} \mathrm{C}$ \\
\hline 8 & KS-8 & Lakhani Pride (Gulistan e Juhar) & $24^{\circ} 54^{\prime} 27.33^{\prime \prime} N$ & $67^{\circ} 8^{\prime} 7.59^{\prime \prime} \mathrm{E}$ & $35-40^{\circ} \mathrm{C}$ \\
\hline 9 & KS-9 & Rado Centre (Gulistan e Juhar) & $24^{\circ} 55^{\prime} 0.11^{\prime \prime} \mathrm{N}$ & $67^{\circ} 7^{\prime} 39.71^{\prime \prime} \mathrm{E}$ & $35-40^{\circ} \mathrm{C}$ \\
\hline 10 & KS-10 & Karachi Centre (Near Centeral Jail) & $24^{\circ} 53^{\prime} 25.73^{\prime \prime} \mathrm{N}$ & $67^{\circ} 3^{\prime} 29.42^{\prime \prime} \mathrm{E}$ & $35-40^{\circ} \mathrm{C}$ \\
\hline 11 & KS-11 & Old Vegitable Market (University Road) & $24^{\circ} 53^{\prime} 52.30^{\prime \prime} \mathrm{N}$ & $67^{\circ} 3^{\prime} 41.58^{\prime \prime} \mathrm{E}$ & $35-40^{\circ} \mathrm{C}$ \\
\hline 12 & KS-12 & PIA planeterium (University Road) & $24^{\circ} 54^{\prime} 25.97^{\prime \prime} \mathrm{N}$ & $67^{\circ} 4^{\prime} 46.23^{\prime \prime} \mathrm{E}$ & $35-40^{\circ} \mathrm{C}$ \\
\hline 13 & KS-13 & Federal Urdu College (University Road) & $24^{\circ} 54^{\prime} 45.46^{\prime \prime} \mathrm{N}$ & $67^{\circ} 5^{\prime} 16.38^{\prime \prime} \mathrm{E}$ & $35-40^{\circ} \mathrm{C}$ \\
\hline 14 & KS-14 & PIB police station (Martin Road) & $24^{\circ} 53^{\prime} 26.70^{\prime \prime} \mathrm{N}$ & $67^{\circ} 3^{\prime} 2.53^{\prime \prime} \mathrm{E}$ & $35-40^{\circ} \mathrm{C}$ \\
\hline 15 & KS-15 & Orangi Police station & $24^{\circ} 56^{\prime} 19.96^{\prime \prime} \mathrm{N}$ & $67^{\circ} 0^{\prime} 13.36^{\prime \prime} \mathrm{E}$ & $30-35^{\circ} \mathrm{C}$ \\
\hline 16 & KS-16 & Banaras Chowk (orangi town) & $24^{\circ} 55^{\prime} 53.03^{\prime \prime} \mathrm{N}$ & $67^{\circ} 0^{\prime} 55.85^{\prime \prime} \mathrm{E}$ & $30-35^{\circ} \mathrm{C}$ \\
\hline 17 & KS-17 & Railway Colony (Lily Bridge Road) & $24^{\circ} 50^{\prime} 38.56^{\prime \prime} \mathrm{N}$ & $67^{\circ} 3^{\prime} 2.26^{\prime \prime} \mathrm{E}$ & $30-35^{\circ} \mathrm{C}$ \\
\hline 18 & KS-18 & Akbar Market (M.A. Jinah Road) & $24^{\circ} 51^{\prime} 40.98^{\prime \prime} \mathrm{N}$ & $67^{\circ} 1^{\prime} 0.45^{\prime \prime} \mathrm{E}$ & $30-35^{\circ} \mathrm{C}$ \\
\hline 19 & KS-19 & Gulberg Square flats (Shahrah e Pakistan) & $24^{\circ} 56^{\prime} 26.92^{\prime \prime} N$ & $67^{\circ} 4^{\prime} 56.72^{\prime \prime} \mathrm{E}$ & $30-35^{\circ} \mathrm{C}$ \\
\hline 20 & KS-20 & KMDC (Allama Rasheed Turabi Road) & $24^{\circ} 56^{\prime} 37.87^{\prime \prime} N$ & $67^{\circ} 3^{\prime} 47.26^{\prime \prime} \mathrm{E}$ & $30-35^{\circ} \mathrm{C}$ \\
\hline 21 & KS-21 & 7-C last stop (Shara e Shair Shah Suri Road) & $24^{\circ} 57^{\prime} 27.26^{\prime \prime} N$ & $67^{\circ} 4^{\prime} 1.15^{\prime \prime} \mathrm{E}$ & $30-35^{\circ} \mathrm{C}$ \\
\hline 22 & KS-22 & Saifi Poly Technique (Allama Rasheed Turabi Road) & $24^{\circ} 55^{\prime} 46.65^{\prime \prime} N$ & $67^{\circ} 3^{\prime} 0.26^{\prime \prime} \mathrm{E}$ & $30-35^{\circ} \mathrm{C}$ \\
\hline 23 & KS-23 & Habib Medical Centre (Shahra e Humayun) & $24^{\circ} 55^{\prime} 9.89^{\prime \prime} \mathrm{N}$ & $67^{\circ} 3^{\prime} 10.13^{\prime \prime} \mathrm{E}$ & $30-35{ }^{\circ} \mathrm{C}$ \\
\hline 24 & KS-24 & Garibabad (Sir Shah Suleman Road) & $24^{\circ} 54^{\prime} 34.58^{\prime \prime} \mathrm{N}$ & $67^{\circ} 3^{\prime} 24.62^{\prime \prime} \mathrm{E}$ & $30-35^{\circ} \mathrm{C}$ \\
\hline 25 & KS-25 & Karchi Zoo (Garden Road) & $24^{\circ} 52^{\prime} 28.49^{\prime \prime} \mathrm{N}$ & $67^{\circ} 1^{\prime} 17.87^{\prime \prime} \mathrm{E}$ & $30-35{ }^{\circ} \mathrm{C}$ \\
\hline 26 & KS-26 & Talimi Bagh (Shahrah e Pakistan) & $24^{\circ} 55^{\prime} 46.96^{\prime \prime} \mathrm{N}$ & $67^{\circ} 4^{\prime} 9.82^{\prime \prime} \mathrm{E}$ & $30-35^{\circ} \mathrm{C}$ \\
\hline
\end{tabular}

Table 2. GPS locations and ambient temperatures of control sites (Karachi).

\begin{tabular}{|c|c|c|c|c|c|}
\hline $\mathbf{S} / \mathbf{N}$ & $\begin{array}{c}\text { Sample } \\
\text { code }\end{array}$ & Location & \multicolumn{2}{|c|}{ GPS location } & Temperature \\
\hline 1 & CKS-1 & Orangi Town (sector \# 5) & $24^{\circ} 56^{\prime} 53.24^{\prime \prime} \mathrm{N}$ & $66^{\circ} 59^{\prime} 6.00^{\prime \prime} \mathrm{E}$ & $28-38^{\circ} \mathrm{C}$ \\
\hline 2 & CKS-2 & Banarus Chowrangi (Orangi town) & $24^{\circ} 56^{\prime} 6.93^{\prime \prime} \mathrm{N}$ & $67^{\circ} 0^{\prime} 39.46^{\prime \prime} \mathrm{E}$ & $28-38^{\circ} \mathrm{C}$ \\
\hline 3 & CKS-3 & Zainab Market (Abdualah Haroon Road) & $24^{\circ} 51^{\prime} 14.47^{\prime \prime} \mathrm{N}$ & $67^{\circ} 1^{\prime} 42.97^{\prime \prime} \mathrm{E}$ & $28-38^{\circ} \mathrm{C}$ \\
\hline 4 & CKS-4 & Akbar Market (M.A. Jinah Road) & $24^{\circ} 51^{\prime} 38.88^{\prime \prime} \mathrm{N}$ & $67^{\circ} 1^{\prime} 6.02 " \mathrm{E}$ & $28-38^{\circ} \mathrm{C}$ \\
\hline 5 & CKS-5 & Jamshaid Road & $24^{\circ} 52^{\prime} 57.35^{\prime \prime} \mathrm{N}$ & $67^{\circ} 2^{\prime} 42.82^{\prime \prime} \mathrm{E}$ & $28-38^{\circ} \mathrm{C}$ \\
\hline 6 & CKS-6 & Jahangir Road & $24^{\circ} 53^{\prime} 23.29^{\prime \prime} \mathrm{N}$ & $67^{\circ} 2^{\prime} 33.98^{\prime \prime} \mathrm{E}$ & $28-38^{\circ} \mathrm{C}$ \\
\hline 7 & CKS-7 & Krimabad (Shahrah e Pakistan) & $24^{\circ} 55^{\prime} 0.65^{\prime \prime} \mathrm{N}$ & $67^{\circ} 3^{\prime} 17.44^{\prime \prime} \mathrm{E}$ & $28-38^{\circ} \mathrm{C}$ \\
\hline 8 & CKS-8 & Aysha Manzil (Shahrah e Pakistan) & $24^{\circ} 55^{\prime} 23.60^{\prime \prime} \mathrm{N}$ & $67^{\circ} 4^{\prime} 4.54 " \mathrm{E}$ & $28-38^{\circ} \mathrm{C}$ \\
\hline 9 & CKS-9 & Gulshan Chowrangi (Rashid Minhas Road) & $24^{\circ} 55^{\prime} 29.75^{\prime \prime} \mathrm{N}$ & $67^{\circ} 5^{\prime} 30.13^{\prime \prime} \mathrm{E}$ & $28-38^{\circ} \mathrm{C}$ \\
\hline 10 & CKS-10 & Rado Centre (Johar More Road) & $24^{\circ} 54^{\prime} 45.40^{\prime \prime} \mathrm{N}$ & $67^{\circ} 7^{\prime} 31.84^{\prime \prime} \mathrm{E}$ & $28-38^{\circ} \mathrm{C}$ \\
\hline
\end{tabular}

(Stone and Droppo, 1996).

By applying the $t$ and p-test, statistical differences between mean values of samples and controls were calculated, $p$-values for all analyzed metals showed that affected samples and control were significantly different. Since all physical and environmental conditions for both sample and control locations were same except auto body refinishing shops. The auto body refinishing shops are the major source of these significant differences. The $\mathrm{Pb}, \mathrm{Cr}, \mathrm{Co}, \mathrm{Cd}, \mathrm{Cu}, \mathrm{Ni}, \mathrm{Mn}, \mathrm{Mo}$ and $\mathrm{Zn}$ concentrations were also considerably higher as compared to control concentration. These metals were actively used in paints 
Table 3. Range, mean, standard deviation, $t$ and $p$-values of analyzed metals collected from Karachi city.

\begin{tabular}{|c|c|c|c|c|c|c|c|c|c|c|}
\hline \multirow{2}{*}{$S / N$} & \multirow{2}{*}{ Metal } & \multicolumn{3}{|c|}{ Sample } & \multicolumn{3}{|c|}{ Control } & \multirow{2}{*}{ t-value } & \multirow{2}{*}{$\begin{array}{c}\text { p- } \\
\text { value }\end{array}$} & \multirow{2}{*}{ Remarks } \\
\hline & & Range (mg/Kg) & $\bar{x}$ & $\pm S D$ & Range $(\mathrm{mg} / \mathrm{Kg}$ ) & $\bar{x}$ & $\pm \mathrm{SD}$ & & & \\
\hline 1 & $\mathrm{Cd}$ & $2.300-9.700$ & 5.390 & 1.861 & $1.340-2.100$ & 1.618 & 0.226 & 10.14 & 0.000 & Significant \\
\hline 2 & Co & $1.300-13.10$ & 6.100 & 3.578 & $0.820-1.800$ & 1.224 & 0.452 & 6.810 & 0.000 & Significant \\
\hline 3 & $\mathrm{Cr}$ & $43.20-100.3$ & 72.42 & 17.51 & $3.560-36.72$ & 23.70 & 13.18 & 9.020 & 0.000 & Significant \\
\hline 4 & $\mathrm{Cu}$ & $14.00-267.3$ & 47.40 & 52.10 & $1.820-10.60$ & 3.908 & 2.616 & 4.250 & 0.000 & Significant \\
\hline 5 & $\mathrm{Fe}$ & $905.1-1813$ & 1327 & 183.9 & $26.40-98.70$ & 71.45 & 19.19 & 34.34 & 0.000 & Significant \\
\hline 6 & $\mathrm{Mn}$ & $31.00-735.8$ & 215.3 & 142.3 & $20.40-98.54$ & 61.32 & 26.83 & 5.280 & 0.000 & Significant \\
\hline 7 & Mo & $4.167-14.33$ & 8.942 & 2.882 & $0.033-3.000$ & 1.547 & 0.776 & 12.00 & 0.000 & Significant \\
\hline 8 & $\mathrm{Ni}$ & $5.800-41.20$ & 12.48 & 6.610 & $0.760-1.700$ & 1.110 & 0.274 & 8.750 & 0.000 & Significant \\
\hline 9 & $\mathrm{~Pb}$ & $173.4-339.6$ & 254.7 & 35.85 & $25.50-386.8$ & 122.5 & 106.0 & 3.860 & 0.002 & Significant \\
\hline 10 & $\mathrm{Zn}$ & $172.2-336.5$ & 206.7 & 43.64 & $1.700-25.16$ & 13.06 & 7.490 & 21.81 & 0.000 & Significant \\
\hline
\end{tabular}

Table 4. Statistical correlations between metals in soil samples $(\mathrm{mg} / \mathrm{kg})$ from different locations of Karachi city.

\begin{tabular}{|l|c|c|c|c|c|c|c|c|c|c|}
\hline Parameter & $\mathbf{P b}$ & $\mathbf{M n}$ & $\mathbf{M o}$ & $\mathbf{Z n}$ & $\mathbf{C u}$ & $\mathbf{N i}$ & $\mathbf{C o}$ & $\mathbf{C d}$ & $\mathbf{C r}$ & $\mathbf{F e}$ \\
\hline $\mathrm{Pb}$ & 1 & & & & & & & & & \\
$\mathrm{Mn}$ & 0.260 & 1 & & & & & & & & \\
$\mathrm{Mo}$ & 0.094 & 0.279 & 1 & & & & & & & \\
$\mathrm{Zn}$ & -0.004 & 0.019 & 0.073 & 1 & & & & & & \\
$\mathrm{Cu}$ & 0.125 & 0.272 & -0.187 & 0.384 & 1 & & & & & \\
$\mathrm{Ni}$ & -0.065 & 0.465 & -0.003 & -0.225 & -0.168 & 1 & & & & \\
$\mathrm{Co}$ & -0.019 & -0.139 & -0.134 & -0.137 & -0.036 & -0.019 & 1 & & & \\
$\mathrm{Cd}$ & -0.0989 & 0.105 & 0.244 & -0.065 & -0.216 & 0.026 & 0.450 & 1 & & \\
$\mathrm{Cr}$ & -0.106 & 0.234 & -0.103 & -0.074 & 0.285 & 0.100 & -0.271 & -0.243 & 1 & \\
$\mathrm{Fe}$ & -0.087 & 0.071 & 0.072 & -0.110 & 0.065 & 0.125 & -0.052 & -0.035 & 0.075 & 1 \\
\hline
\end{tabular}

to produce different colors, which were used for refinishing of vehicles. Table 4 shows the correlation matrix for paired variables for the metals in soil samples in Karachi city. There was no significant correlation between the metal contents in Karachi city; only Co and Cd show a weak correlation of 0.450 .

One of the valuable statistical applications of PCA was also applied. Figure 1 shows score plots as a result of PCA for metal load, it showed a good evidence for prominent difference in pollution profile, in the graph, the right hand sides of samples were taken as controls.

Figures 2 and 3 show the concentration of metals in soils samples. Figure 2 represents the concentrations of $\mathrm{Fe}, \mathrm{Mn}, \mathrm{Pb}, \mathrm{Zn}$ and $\mathrm{Cr}$ metals. The Fe content showed exponentially higher concentration in all analyzed samples. The reason of this Fe content is the scraping process. Sample KS-04 and KS-14 showed higer concentration of Mn, most of the autobody shops were using Mn based color paints. Sample KS-19, KS-23, KS-25 and KS-26 showed higher concentration of $\mathrm{Zn}$ as compare to $\mathrm{Mn}, \mathrm{Pb}$ and $\mathrm{Cr}$ metals. Most of the auto body refinishing shops deals in white colors which are $\mathrm{Zn}$ based paint. The $\mathrm{Pb}$ content is also used in many colors, so all samples have considerable concentration of $\mathrm{Pb} . \mathrm{Cr}$ is mainly used in green color paints and also in Cr plating. $\mathrm{Cr}$ is dangerous to human health, because it causes stomach acidity leading to ulcer and lung cancer (Kenaga, 1980). Figure 3 represents the concentration of $\mathrm{Mo}, \mathrm{Cu}, \mathrm{Ni}, \mathrm{Co}$ and $\mathrm{Cd}$. The Cu contents were higher in all samples as compare to others five metals. $\mathrm{Cu}$ is frequently used in blue color paints. Cu may cause nausea, diarrhoea, salivation and gastrointestinal haemorrhage (Huang and Shin, 1993). The Mo, Cu, Ni, $\mathrm{Co}$ and $\mathrm{Cd}$ metals shown in Figure 3 are less used in auto paints as compare to other combination of metals ( $\mathrm{Fe}, \mathrm{Mn}, \mathrm{Pb}, \mathrm{Zn}$ and $\mathrm{Cr}$ ) as shown in Figure 2.

\section{Conclusion}

There are many occupations and professions which are running in industrial and residential areas. The "Auto body refinishing" is such kind of occupation which affects the environment, especially on the workers and exposed soil. Particularly, the painting and scrapping process were done without any safety measures. Metal pigments in paints and scrap are continuously deposited with effects on the workers and on soil. The results of the present 


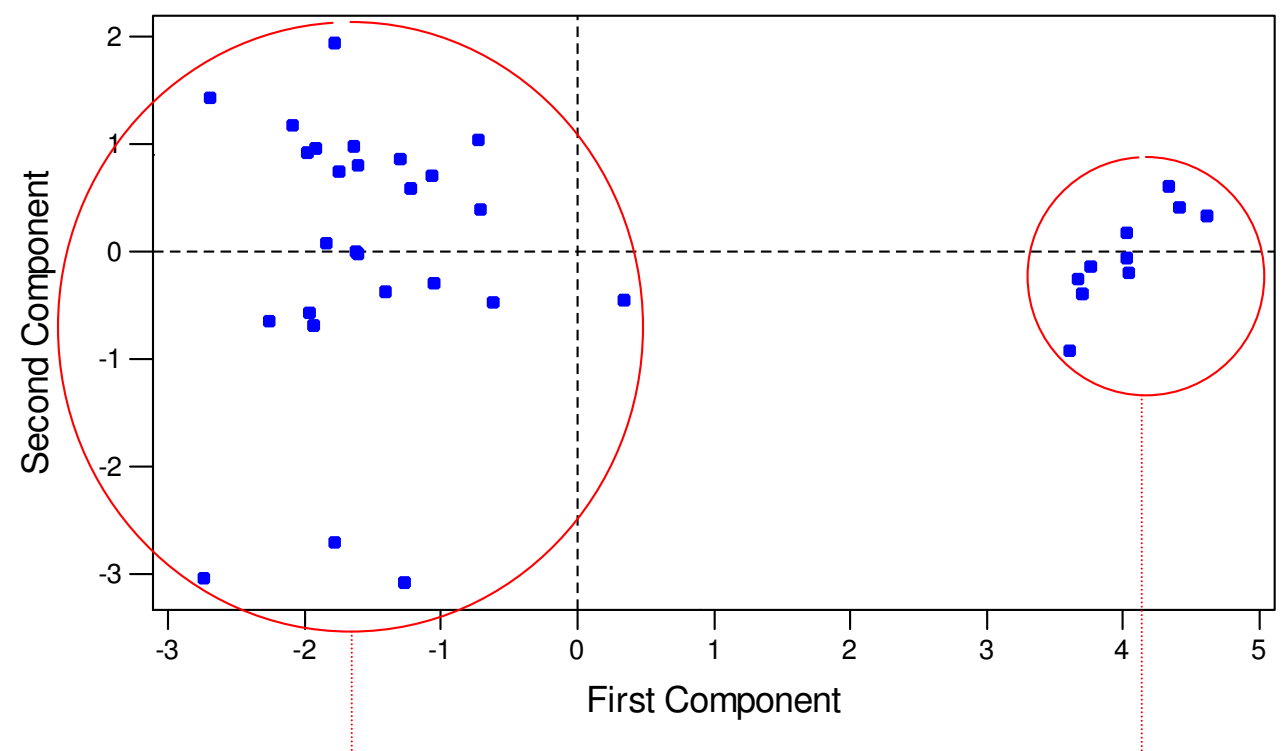

Controls

Samples

Figure 1. PCA for samples and control samples of Karachi.

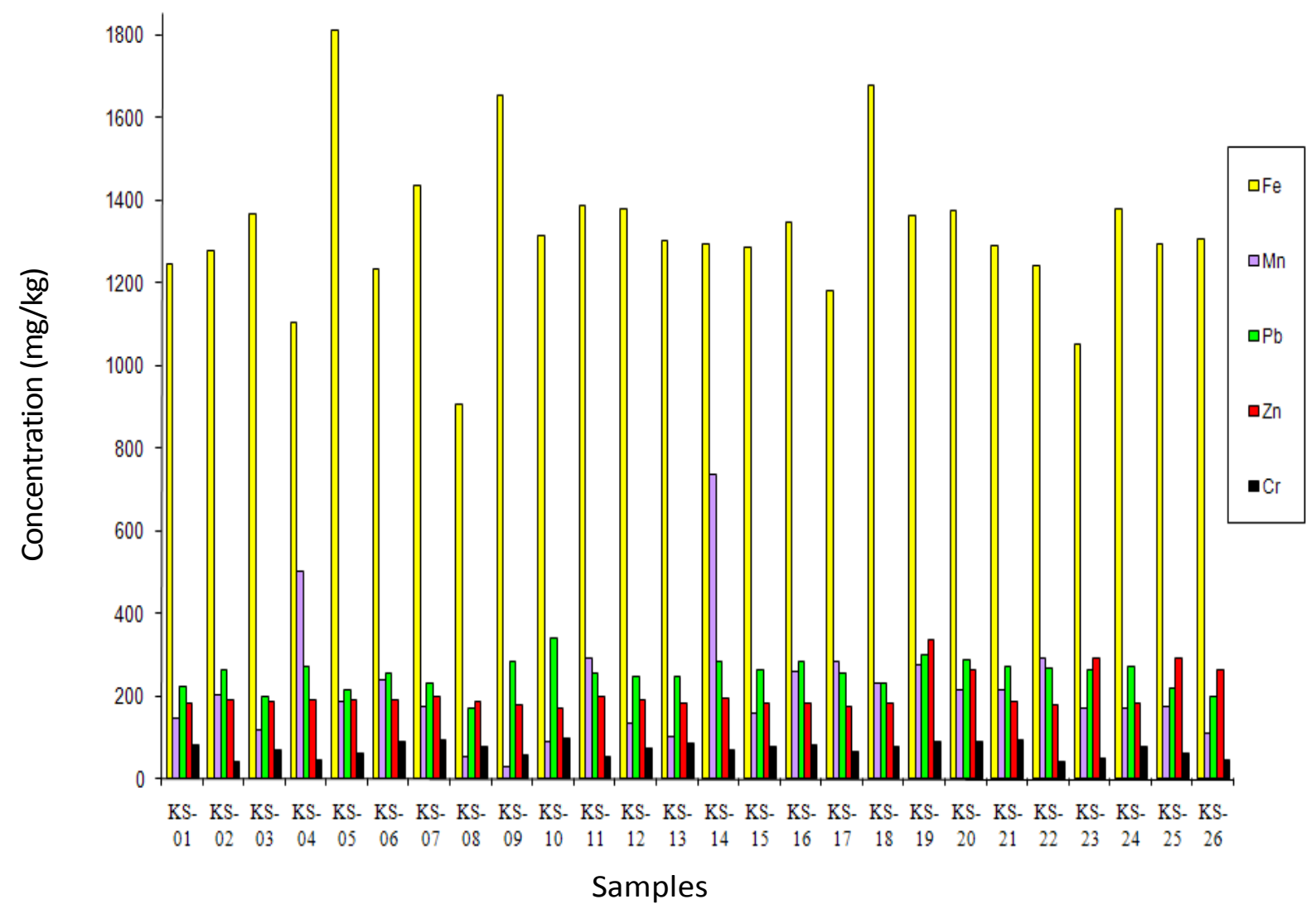

Figure 2. Levels of trace metals $(\mathrm{mg} / \mathrm{kg})$ in soil samples of karachi city ( $\mathrm{Fe}, \mathrm{Mn}, \mathrm{Pb}, \mathrm{Zn}, \mathrm{Cr})$. 


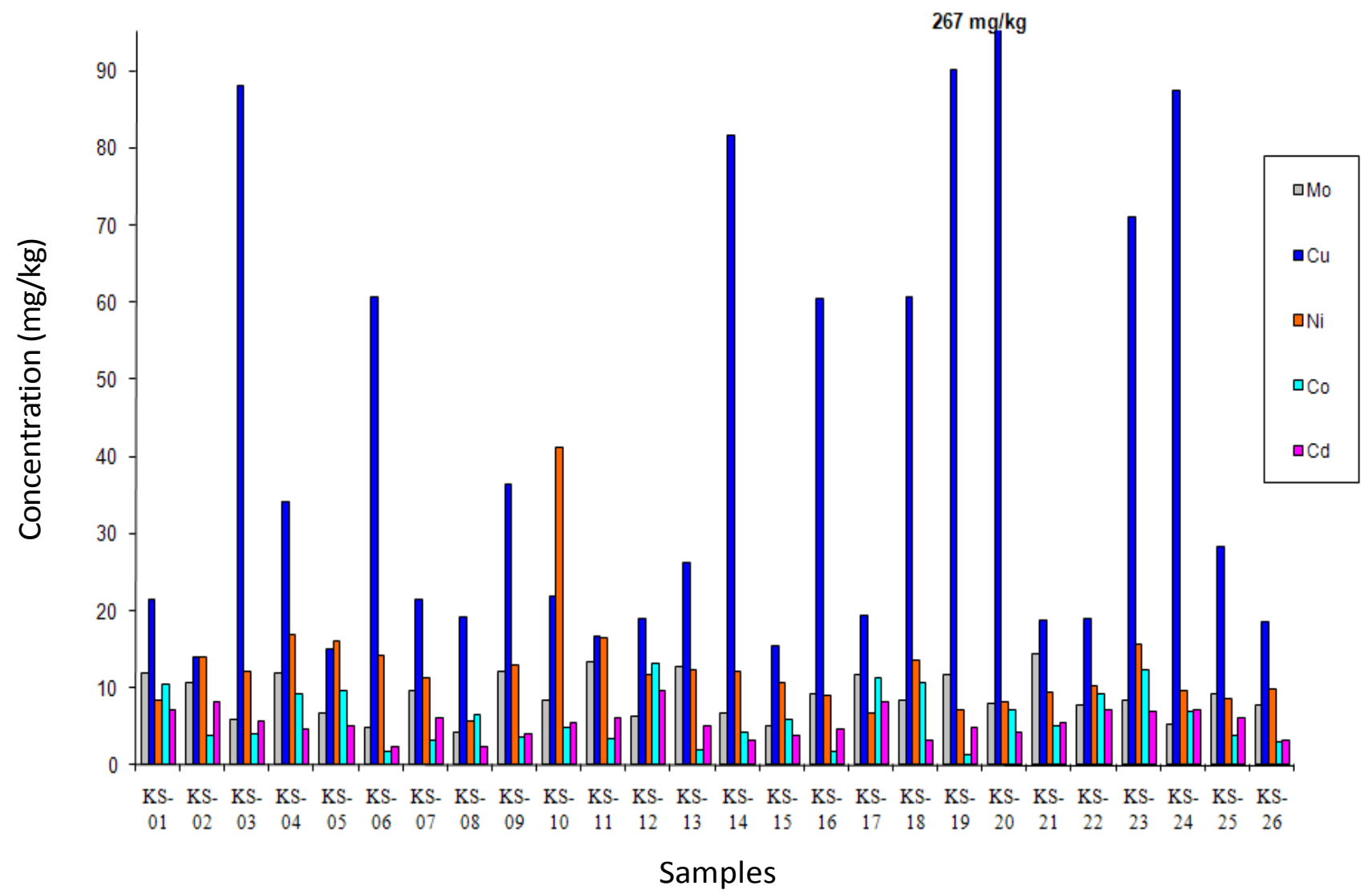

Figure 3. Levels of trace metals (mg/kg) in soil samples of karachi city (Mo, Cu, Ni, Co, Cd).

study showed that the soil around these auto body refinishing areas were contaminated exponentially due to gradually increase in the auto body refinishing shops which is a great threat to the environment. The levels of $\mathrm{Pb}, \mathrm{Mn}, \mathrm{Fe}, \mathrm{Cr}, \mathrm{Zn} \mathrm{Cd}$, Co, Ni, Mo and Cu contents were higher than the control samples. It shows an alarming situation. The remedial measures will be adopted to reduce the level of metal contents.

\section{REFERENCES}

American Automotive Manufacturers Association (AAMA) (1997). Progress measurements in US Automotive Pollution Prevention Project, www.aama.comlenvironment.

Baath E (1989). Effects of Heavy Metals In Soil On Microbial Processes and Populations. Water. Air. Soil Pollut. 47: 335-379.

Baker AJM, Brooks RR (1989). Terrestrial higher plants which hyperaccumulate metallic elements-a review of their distribution, ecology and phytochemistry. Biorecovery, 1: 81-126.

Charlesworth SM, Lees JA (1999). The Distribution Of Heavy metals In Deposited Urban Dusts And Sediments, Coventry, England. Environ. Geochem. Health, 21: 97-115.

Cocker DR, Shah SD, Johnson K, Miller JW (2004). Norbeck JM. Development and application of a mobile laboratory for measuring emissions from diesel engines. Environ. Sci Technol. 38(7): 21822189.

Duxbury T (1985). Ecological aspects of heavy metal responses in microorganisms In: Marshall KC, New York, Plenum Press. Adv. Microb. Ecol. pp. 185-235.
Farrell L (2002). Rehabilitation at Silvermines, Extract. Ind. Ireland Ann. Rev. pp. 41-45.

Fergusson JE, Ryan DE (1984). The elemental composition of street dust from large and small urban areas related to city type, source and particle size. Sci. Total. Environ. 34: 101-116.

Guitao S, Chen Z, Xu S, Zhang J, Wang Li B, Teng C (2008). Potentially toxic metal contamination of urban soils and roadside dust in Shanghai, China. Environ. Pollut. 156(2): 251-260.

Kenaga EE (1980). Correlation of bioconcentration factors of chemicals in aquatic and terrestrial organisms with their physical and chemical properties. Environ. Sci. Technol. 14 (5): 553-562.

ISO, Soil quality, Extraction of trace elements soluble in aqua-regia, International standard, 1-6. ISO 11466, (1995) (E).

Jeffrey BR, Hudson G (2001). A flexible methodology for the characterization of soils: a case study of the heavy metal status of a site at Dornach. Sci. Total Environ. 264: 153-162.

Jolliffe IT (2002). Principal Component Analysis (Spring series in statistics). $2^{\text {nd }}$ Edition, Springer. pp. 1-3.

Toda K, Ohba T, Takaki M, Karthikeyan S, Hirata S, Dasgupta PK (2005). Anal. Chem. 1, 77(15): 4765-4773.

Knight B, Zhao FJ, McGrath SP, Shen ZG (1997). Zinc and cadmium uptake by the hyperaccumulator Thlaspi caerulescens in contaminated soils and its effects on the concentration and chemical speciation of metals in soil solution. Plant Soil, 197: 71-78.

Lowell J, Plumb S, Sorge M, Winter D (1993). Hazardous waste: the auto industry's $\$ 500$ billion mess? WARD's Auto World, July 1993 , pp. 34-47.

Manta DS, Angelone M, Bellanca A, Neri R, Sprovieria M (2002). Heavy metals in urban soils: a case study from the city of Palermo (Sicily), Italy. Sci. Total. Environ. 300: 229-243.

Stone M, Droppo IG (1996). Distribution of lead, copper and zinc in size-fractionated river bed sediment in two agricultural catchments of 
southern Ontario, Canada.. Environ. Pollut. 93(3): 353 - 362.

Nallicheri R (1993). Automotive Painting: An Economic and Strategic Analysis. S.M. Thesis, Sloan School of Management, Massachusetts Institute of Technology, Cambridge, Massachusetts.

Nielsen J, Sango C, Winroth G, Hallberg T, Skerfving S (1985). Systemic reactions associated with polyisocyanate exposure. Scand. J. Work. Environ. Health, 11(1): 51-54.

Omar NYMJ, Abas MRB, Rahman NA, Tahir NM, Rushdi Al (2007). Simoneit BRT. Levels and distributions of organic source tracers in air and roadside dust particles of Kuala Lumpur, Malaysia. Environ. Geol. 52: 1485-1500.

Ozan D, Yaya O, Alaghab G (2008). Multivariate statistics to investigate metal contamination in surface soil. J. Environ. Manage. 86: 581594.

Praschan E (1994). What the clean air act means to the auto industry. Automotive Body Painting Proceedings of the International Body Engineering Conference. Warren, Michigan, IBEC Ltd. Publications, pp. 78-81.

Request for comments: automobile refinishing solvent use survey. Federal Register 61(February 9, 1996) p. 4992.

Richard D, Pearson G (1998). The Ecology of Industry: Sectors and Linkages. National Academy of Engineering, National Academy Press, Washington, D.C.

Richard T, Enander D, Gute M, Missaghian R (1998). Survey of Risk Reduction and Pollution Prevention Practices in the Rhode Island Automotive Refinishing Industry. Am. Ind. Hyg. Assoc. J. 59: 478489.

Rogge WF, Mazurek MA, Hildemann LM, Cass GR (1993). Simoneit BRT. Quantification of urban organic aerosols at a molecular level: identification, abundance and seasonal variation. Atmos. Environ. 27: 1309-1330.

Huang SDA, Shin KY (1993). Spectro. Chemic. Acta. 48B(12): 14511460.
Selden A, Belin L, Wass U (1989). Isocyanate exposure and hypersensitivity pneumonitisĐreport of a probable case and prevalence of specic immunoglobulin $\mathrm{G}$ antibodies among exposed individuals. Scand. J. Work. Environ. Health, 15(3): 234-237.

Tahir H, Saleem M, Afzal M, Hussain ST (2000). Trace metals pollution assessment of sediments and liquid wastes from textile industries of Pakistan. J. Trace. Microprob. T. 18(1): 99-106.

Tahir H (2004). Heavy metal pollution status of sediment and liquid wastes from fertilizer industries, Hattar, Pakistan. Saudi J. Chem. Soc. 8(2): 213-222.

Tahir H (2005). Comparative trace metal contents in sediments and liquid wastes from tanneries and the removal of chromium using zeolite-5A. Electron. J. Environ. Agric. Food Chem. EJEAFCHe, 4(4): 1021-1032.

Tahir H, Mushtaque Z (2005). Assistment of soil samples after the disaster of Tasman sprit near the Clifton beach of Karachi, Pakistan. Electron. J. Environ. Agric. Food Chem. EJEAFCHe, 4(6): 10941101.

Tornling G, Alexandersson R, Hedenstierna G, Plato N (1990). Decreased lung function and exposure to diisocyanates (HDI and HDI-BT) in car repair painters: observations on re-examination 6 years after initial study. Am. J. Ind. Med. 17(3): 299-310.

U.S. Environmental Protection Agency(1996). Toxic Release Inventory, EPA-745-R-98-005, Office of Pollution Prevention and Toxics, Washington, D.C.

Zhou JM, Dang Z, Cai MF, Liu CQ (2007). Soil Heavy Metal Pollution Around the Dabaoshan, Mine, Guangdong Province, China. Pedosphere, 17(5): 588-594. 